RESEARCH ARTICLE

\title{
Radiolabeled APIs for the Conduct of Human ADME Studies of Oncology Compounds
}

\author{
Yuexian Li*, Mihaela Plesescu and Shimoga R Prakash \\ Department of Drug Metabolism and Pharmacokinetics, Takeda Pharmaceuticals International Co., USA
}

*Corresponding author: Yuexian Li, Department of Drug Metabolism and Pharmacokinetics, Takeda Pharmaceuticals International Co., 40 Landsdowne Street, Cambridge, MA 02139, USA, Tel: +1-617-444-1275, Fax: +1-617-444-1480, E-mail: yuexianfrank.li@takeda.com

\begin{abstract}
Human ADME (Absorption, Distribution, Metabolism, and Excretion) studies of new chemical entities are an important part of the drug development process. These studies are normally performed by using a radioactive tracer $(\mathrm{C}-14$ or $\mathrm{H}-3$ ) blended with a therapeutic dose of non-radioactive drug in about four to six subjects. The radiolabeled API (Active Pharmaceutical Ingredient) is utilized to evaluate the recovery and track the metabolic fate and physiological disposition of the drug. More challenges are faced regarding subject and site selection and supply of $\mathrm{C}-14$ labeled drug product when performing these studies with oncology compounds. If the compound is suitable to study in healthy volunteers, the strategy employed will be similar to what is normally conducted with non-oncology compounds. But if the compound is not suitable to study in healthy volunteers (e.g. a cytotoxic drug), different strategies including recruitment of patients and availability of pure radioactive drug product whenever a patient becomes available for the study must be employed. These studies generally extend over a period of six months to a year. Because of this, stability studies of manufactured radiolabled compound assume importance. Two approaches (Microtracer-AMS (Accelerator Mass Spectrometry) and the traditional method) used for these studies will be described. Detailed information will be explained by using three examples (Compounds A, B, and $C$, with microtracer - AMS method in healthy volunteers, microtracer - AMS method in patients, and traditional method in patients respectively).
\end{abstract}

\section{Keywords}

Human ADME, Oncology compounds, Radiolabeled API, Stability, AMS

\section{Introduction}

Human ADME study (Absorption, Distribution, Metabolism, and Excretion) is an important and essential part of the drug development process. It is completed by using a radioactive tracer ( $\mathrm{C}-14$ or $\mathrm{H}-3$ ) blended with the therapeutic dose of non-radioactive test drug. Its objectives are to determine the route of excretion of compound related material, identify metabolites of a test compound, and describe the exposure of test compound metabolites [1-9].

Depending on non-clinical and clinical toxicological profiles of oncology compounds, human ADME studies can be conducted in either healthy volunteers or oncology patients. At Takeda, majority of the studies had to be conducted in patients. If human ADME studies are conducted in patients, we have to face difficult subject recruitment, limited options of clinical sites, preparation of radioactive drug for each patient, and a longer period of stability study for the radiolabeled API (Active Pharmaceutical Ingredient). But if conducted in healthy volunteers, we will have relatively easier subject recruitment, more options of clinical sites, one batch preparation of radiolabeled drug for all subjects at the same time, and a shorter period of stability study for the radiolabeled API.

\section{Methods}

There are two methods for human ADME studies. Method 1 is Microtracer dose-AMS (Accelerator Mass Spectrometry) method [2,3,10-13]. In this method, the radioactivity per subject is normally $0.2-1.0 \mu \mathrm{Ci}$. The weight of radiolabeled compound per person is in $\mu \mathrm{g}$ level. The GMP (Good Manufacturing Practices) synthesis of labeled compound is generally not required. The rat dosimetry information is also not required. But AMS

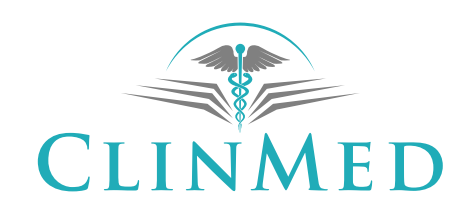

INTERNATIONAL LIBRARY

Citation: Li Y, Plesescu M, Prakash SR (2017) Radiolabeled APIs for the Conduct of Human ADME Studies of Oncology Compounds. Int J Cancer Clin Res 4:082. doi.org/10.23937/2378-3419/1410082 Received: May 30, 2017; Accepted: August 28, 2017; Published: August 30, 2017

Copyright: (C) $2017 \mathrm{Li} \mathrm{Y}$, et al. This is an open-access article distributed under the terms of the Creative Commons Attribution License, which permits unrestricted use, distribution, and reproduction in any medium, provided the original author and source are credited. 
method might be sensitive to the contamination at the clinical site. Generally, the AMS analysis is more expensive and time consuming.

Method 2 is the Traditional (GMP radiolabeled compound-LSC (Liquid Scintillation Counting)) method. In this method, radioactivity per subject is $50-100 \mu \mathrm{Ci}$. The weight of radiolabeled compound per person is normally in mg level. The GMP synthesis of labeled compound is required. This method is less sensitive to the contamination at the clinical site. But the tissue distribution data in rats and dosimetry information are required.

\section{Results}

We use three examples to explain these two methods. Two examples are from the AMS method either in healthy volunteers or patients. The third example is from the traditional method in patients.

Example 1 was a human ADME study of Compound A by using Microtracer-AMS method in healthy volunteers. Compound $A$ is safe enough to be administered in healthy subjects. Human dosing considerations included 6 healthy volunteers, $0.5 \mu \mathrm{Ci}$ (32 ng) per subject, and single oral solution dose $(100 \mathrm{~mL}$ of citrate buffer solution per subject). The large volume $(100 \mathrm{~mL})$ is needed because of its high dose. We used the ethanol solution of $\left[{ }^{14} \mathrm{C}\right]$-Compound $\mathrm{A}$ as the spiking solution for the radioactive formulation. This is because Compound $A$ is very soluble in ethanol. Ethanol can stabilize the radiolabeled compound. It is also convenient for addition of a small amount of $\left[{ }^{14} \mathrm{C}\right]$-Compound $\mathrm{A}$ (32 $\mathrm{ng}$ ) into the formulation. The concentration of the spiking solution was $0.5 \mu \mathrm{Ci}$ in $0.5 \mathrm{~mL}$ ethanol per subject. The radioactive formulation was prepared at the clinical site. The Clinical CRO (Contract Research Organization) transfer-related activities are summarized in Table 1.

$\left[{ }^{14} \mathrm{C}\right]$-Compound $\mathrm{A}$ formulation was stable at $5{ }^{\circ} \mathrm{C}$ for

Table 1: Clinical CRO transfer-related activities.

\begin{tabular}{|l|l|}
\hline Activity & Organization \\
\hline Transfer of radiolabeled formulation method & Takeda \\
\hline $\begin{array}{l}\text { Transfer of analytical method } \\
\text { mock run }\end{array}$ & Takeda \\
\hline $\begin{array}{l}\text { Generation of formulation batch records (mock } \\
\text { and real runs) }\end{array}$ & CRO \\
\hline $\begin{array}{l}\text { QC data and release } \\
\text { Review of batch records }\end{array}$ & CRO \\
\hline
\end{tabular}

24 hours plus at room temperature for 4 hours. These stability conditions mimicked the actual clinical operations. Three different higher concentrations $(2.5 \mu \mathrm{Ci} / \mathrm{mL}$, $5 \mu \mathrm{Ci} / \mathrm{mL}, 10 \mu \mathrm{Ci} / \mathrm{mL}$ ) of solutions were prepared for the stability study because the radiometric detector cannot be used for the low radioactive concentration $(0.5 \mu \mathrm{Ci}$ in $100 \mathrm{ml}$ of citrate buffer solution). This stability study assumed that the stability of a radioactive formulation should be same or even better with the lower concentration. The ethanol spiking solution of $\left[{ }^{14} \mathrm{C}\right]$-Compound A was stable for more than a year.

Example 2 was a human ADME study of Compound $B$ by using Microtracer-AMS Method in patients. The ADME Study was in patients because Compound B is cytotoxic. This study was utilizing a single oral solution dose. Each subject was administered 0.4-0.6 $\mu \mathrm{Ci}$ $\left[{ }^{14} \mathrm{C}\right]$-Compound $\mathrm{B}$ (21-37 ng API at specific activity of $16.6 \mu \mathrm{Ci} / \mathrm{mg}$ ) in $10 \mathrm{~mL}$ citrate buffer (pH 5.8). The specific $\mathrm{pH}(5.8)$ is required for a good solubility and stability. $\left[{ }^{14} \mathrm{C}\right]$-Compound $\mathrm{B}$ spiking solution was prepared by using a citrate buffer $(\mathrm{pH} 5.8)$ at a concentration of $0.83 \mu \mathrm{Ci} / \mathrm{mL}$. A higher concentrations $(2 \mu \mathrm{Ci} / \mathrm{mL})$ of spiking solution was utilized for the stability study because $0.83 \mu \mathrm{Ci} / \mathrm{mL}$ was too low to be analyzed by a radiometric detector. $\left[{ }^{14} \mathrm{C}\right]$-Compound $\mathrm{B}$ dosing solution was prepared by adding the spiking solution into the Compound $B$ dissolved in citrate buffer $(\mathrm{pH} \mathrm{5.8,10} \mathrm{mL).} \mathrm{Because}$ the concentration $(0.06 \mu \mathrm{Ci} / \mathrm{mL})$ of the dosing solution is also too low to be analyzed by radiometric detector, three higher concentrations $(10 \mu \mathrm{Ci} / 10 \mathrm{~mL}, 15 \mu \mathrm{Ci} / 10$ $\mathrm{mL}$, and $20 \mu \mathrm{Ci} / 10 \mathrm{~mL}$ ) were prepared for the stability study.

Our clinical operations team, like others, always wants to know the timelines of the radioactive API and formulation related activities before selection of a clinical site that are summarized in Table 2. $\left[{ }^{14} \mathrm{C}\right]$-Compound B API was stable only for 26 weeks at $-80^{\circ} \mathrm{C}$ (Table 3 ).

Table 2: Timelines of microtracer dose-AMS method.

\begin{tabular}{|l|l|}
\hline Activity & Time, month \\
\hline Preparation of $\left[{ }^{14} \mathrm{C}\right]-\mathrm{API}$ & $1-3$ \\
\hline Develop and prepare spiking solution & 1 \\
\hline Radiolabeled formulation and stability study & $1-2$ \\
\hline $\begin{array}{l}\text { Write CMC radiolabeled portion for IND } \\
\text { Amendment }\end{array}$ & 1 \\
\hline Mock run, review of batch records & 1 \\
\hline Total & $5-8$ \\
\hline
\end{tabular}

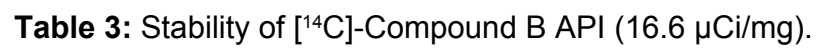

\begin{tabular}{|l|l|l|l|l|}
\hline $\begin{array}{l}\text { Time point at } \mathbf{- 8 0} \\
{ }^{\mathbf{}} \mathbf{C} \text {, week }\end{array}$ & Chemical purity, $\%$ & $\begin{array}{l}\text { Largest chemical } \\
\text { impurity, \% }\end{array}$ & $\begin{array}{l}\text { Radiochemical purity, } \\
\text { \% }\end{array}$ & $\begin{array}{l}\text { Largest radiochemical } \\
\text { impurity, } \%\end{array}$ \\
\hline Initial & 99.9 & 0.1 & 99.4 & 0.2 \\
\hline 7 & 99.5 & 0.2 & 99.0 & 0.3 \\
\hline 11 & 99.1 & 0.3 & 98.9 & 0.3 \\
\hline 14 & 0.3 & 98.1 & 0.5 \\
\hline 18 & 98.8 & 0.4 & 98.0 & 1.1 \\
\hline 22 & 98.6 & 0.5 & 97.6 & 0.7 \\
\hline 26 & 98.6 & 0.7 & 97.2 & 0.9 \\
\hline
\end{tabular}


Table 4: Stability of $\left[{ }^{14} \mathrm{C}\right]$-Compound B spiking solution $(2 \mu \mathrm{Ci} / \mathrm{mL})$.

\begin{tabular}{|l|l|l|}
\hline $\begin{array}{l}\text { Time point } \\
\text { at room } \\
\text { temperature, } \mathbf{h}\end{array}$ & $\begin{array}{l}\text { Radiochemical } \\
\text { purity, \% }\end{array}$ & $\begin{array}{l}\text { Largest individual } \\
\text { radiochemical } \\
\text { impurity, \% }\end{array}$ \\
\hline Initial & 97.29 & 1.00 \\
\hline 2 & 97.18 & 1.00 \\
\hline 4 & 97.00 & 1.21 \\
\hline 6 & 96.93 & 1.70 \\
\hline
\end{tabular}

Table 5: Stability of $\left[{ }^{14} \mathrm{C}\right]$-Compound B dosing solution $(10 \mu \mathrm{Ci} / 10$ $\mathrm{mL})$.

\begin{tabular}{|l|l|l|}
\hline $\begin{array}{l}\text { Time point } \\
\text { at room } \\
\text { temperature, } \mathbf{h}\end{array}$ & $\begin{array}{l}\text { Radiochemical } \\
\text { purity, \% }\end{array}$ & $\begin{array}{l}\text { Largest individual } \\
\text { radiochemical } \\
\text { impurity, \% }\end{array}$ \\
\hline Initial & 97.28 & 1.05 \\
\hline 2 & 97.11 & 1.35 \\
\hline 4 & 97.01 & 1.30 \\
\hline 6 & 96.86 & 1.19 \\
\hline 8 & 96.64 & 1.67 \\
\hline
\end{tabular}

Table 6: CMO transfer-related activities.

\begin{tabular}{|l|l|}
\hline Activity & Organization \\
\hline Transfer radiolabeled synthetic methods & Takeda \\
\hline Transfer analytical methods & Takeda/CMO \\
\hline $\begin{array}{l}\text { Test synthetic methods by unlabeled and } \\
\text { labeled compounds }\end{array}$ & CMO \\
\hline Technical batch API synthesis & CMO \\
\hline GMP synthesis of radiolabeled API & CMO \\
\hline QC data & CMO \\
\hline Generation of batch records & CMO \\
\hline $\begin{array}{l}\text { Review of batch records and analytical data } \\
\text { Prepare stability protocol and analyze } \\
\text { samples }\end{array}$ & Takeda \\
\hline $\begin{array}{l}\text { Approve and release the radiolabeled API for } \\
\text { clinical use }\end{array}$ & Takeda \\
\hline
\end{tabular}

Two batches of $\left[{ }^{14} \mathrm{C}\right]-\mathrm{API}$ were required to complete the human ADME study. Spiking solution $(2 \mu \mathrm{Ci} / \mathrm{mL})$ was stable for 4 hours at room temperature $(0.3 \%$ decomposition was within the specifications that require radiochemical purity should be larger or equal to $97.0 \%$ and individual impurity less or equal to $2.0 \%$ ) (Table 4). $\left[{ }^{14} \mathrm{C}\right]$-Compound $\mathrm{B}$ dosing solution $(10 \mu \mathrm{Ci} / 10 \mathrm{~mL})$ was also stable for 4 hours at room temperature $(0.3 \%$ decomposition was within the specifications) (Table 5).

Example 3 was a human ADME study of Compound $C$ by utilizing the Traditional Method in patients. The study was in patients because of Compound C's cytotoxicity. The study was designed by administering 4-6 Patients. Each patient was dosed $80-100 \mu \mathrm{Ci}$ with a single oral solution.

A CMO (Contract Manufacturing Organization) was required for the synthesis of GMP $\left[{ }^{14} \mathrm{C}\right]$-Compound $\mathrm{C}$ API. The selection of the CMO was according to the following considerations at Takeda:

- Technical capability and experience in radiolabeled synthesis.

- Analytical capability for in-process and release analysis.
Table 7: Timelines of traditional method in API and formulation portions.

\begin{tabular}{|l|l|}
\hline Activity & Time, month \\
\hline Develop radio-synthetic route & 2 \\
\hline GMP synthesis at CMO & $5-7$ \\
\hline Radiolabeled formulation and stability study & $1-2$ \\
\hline $\begin{array}{l}\text { Write CMC radiolabeled portion for IND } \\
\text { Amendment }\end{array}$ & 1 \\
\hline Mock run, review of batch records & 1 \\
\hline Total & $10-13$ \\
\hline
\end{tabular}

Table 8: Stability of $\left[{ }^{14} \mathrm{C}\right]$-Compound C API $(2.23 \mu \mathrm{Ci} / \mathrm{mg})$.

\begin{tabular}{|l|l|l|}
\hline $\begin{array}{l}\text { Time point at } \\
\mathbf{- 8 0} \mathbf{~ C}\end{array}$ & Chemical purity, \% & $\begin{array}{l}\text { Radiochemical } \\
\text { purity, \% }\end{array}$ \\
\hline Initial & 99.7 & 100 \\
\hline 1 Month & 99.7 & 100 \\
\hline 2 Month & 99.7 & 100 \\
\hline$\ldots \ldots$. & & \\
\hline 12 Month & 99.7 & 100 \\
\hline
\end{tabular}

Table 9: Stability of $\left[{ }^{14} \mathrm{C}\right]$-Compound $\mathrm{C}$ dosing solution $(6.0 \mu \mathrm{Ci} /$ $\mathrm{mL}$ ).

\begin{tabular}{|l|l|l|}
\hline Time point & Chemical purity, \% & Radiochemical purity, \% \\
\hline Initial & 99.7 & 100 \\
\hline $\begin{array}{l}24 \mathrm{~h} \text { at } 5{ }^{\circ} \mathrm{C} \\
94 \mathrm{~h} \text { at } 5{ }^{\circ} \mathrm{C}\end{array}$ & 99.7 & 100 \\
\hline $\begin{array}{l}\text { + } \mathrm{h} \text { at room } \\
\text { temperature }\end{array}$ & & 100 \\
\hline
\end{tabular}

\section{- $\quad$ QC and QA to support GMP operations.}

To make the GMP preparation of $\left[{ }^{14} \mathrm{C}\right]-A P I$ smooth, we followed the last-step procedures of un-labeled GMP synthesis and crystallization with some minor modification. The advantages of doing so are the availability of validated analytical methods, impurity profile, and other synthetic and analytical information. Smoother transfer of manufacturing and analytical details to $\mathrm{CMO}$ is usually feasible because of prior optimization work at the existing radiochemistry unit at Takeda. Due to a requirement for GMP qualification of existing radiochemistry unit at Takeda with appropriate SOPs and instrument qualifications, working with a qualified $\mathrm{CMO}$ is preferred. This trend of using GMP qualified vendors for manufacture of radiolabeled API is more prevalent in the industry. Based on the survey conducted by $\mathrm{IQ}$, for a radiolabeled human ADME study, a one-time event, question of GMP synthesis of API is still under debate [14].

The CMO transfer-related activities are summarized in Table 6. The timelines related to API and formulation portions are summarized in Table 7 . The $\left[{ }^{14} \mathrm{C}\right]$-API was found stable at least 1 year at $-80^{\circ} \mathrm{C}$ (Table 8). Stability in general is compound dependent, and Compound $\mathrm{C}$ is much more stable than Compound $\mathrm{B}$ (Table 3 ). The dosing solution was stable 24 hours at $5^{\circ} \mathrm{C}$ plus 4 hours at room temperature (Table 9). These stability conditions mimicked the actual clinical operations.

\section{Conclusions}

In general for oncology compounds, it is essential to 
have capability to prepare a minimum of two batches of radiolabeled API during human ADME study because of delays in patient recruitment and stability of API. For the GMP preparation of radiolabeled API, it is preferable to follow the last-step procedures of unlabeled GMP synthesis and crystallization with some minor modification. Confirmation of stability for longer periods of time by appropriate storage is required.

\section{Acknowledgements}

Thanks are due to the Process Chemistry, Analytical Development, QA, QC, Formulation, Clinical Pharmacology, Clinical Operations, and DMPK departments of Takeda-Boston.

\section{References}

1. Marathe PH, Shyu WC, Humphreys WG (2004) The use of radiolabeled compounds for ADME studies in discovery and exploratory development. Curr Pharm Des 10: 29913008.

2. Beumer JH, Garner RC, Cohen MB, Galbraith S, Duncan GF, et al. (2007) Human mass balance study of the novel anticancer agent ixabepilone using accelerator mass spectrometry. Invest New Drugs 25: 327-334

3. Beumer JH, Beijnen JH, Schellens JH (2006) Mass balance studies with a focus on anticancer drugs. Clin Pharmacokinet 45: 33-58.

4. Dain JG, Collins JM, Robinson WT (1994) A regulatory and industrial perspective on the use carbon-14 and tritium isotopes in human ADME studies. Pharm Res 11: 925-928.

5. Suri A, Pusalkar S, Li Y, Prakash S (2016) Absorption, distribution, and excretion of the investigational agent Orteronel (TAK-700) in healthy male subjects: a Phase 1, open-label, single-dose study. Clin Pharmacol Drug Develop 5: 180-187.
6. Lappin G (2016) Approaches to intravenous clinical pharmacokinetics: Recent developments with isotopic microtracers. J Clin Pharmacol 56: 11-23.

7. Penner N, Xu L, Prakash C (2012) Radiolabeled absorption, distribution, metabolism, and excretion studies in drug development: why, when, and how? Chem Res Toxicol 25: 513-531.

8. US Food and Drug Administration (FDA) (2010) The Radioactive Drug Research Committee: Human research without an investigational new drug application. Department of Health and Human Services, Food and Drug Administration, Center for Drug Evaluation and Research, Center for Biologics Evaluation and Research.

9. European Medicines Agency (2013) Guideline on the investigation of drug interactions. Committee for Human Medicinal Products.

10. Comezoglu SN, Ly VT, Zhang D, Humphreus WG, Bonacorsi SJ, et al. (2009) Biotransformation profiling of [(14) C]ixbepilone in human plasma, urine and feces samples using accelerator mass spectrometry (AMS). Drug Metab Pharmacokinet 24: 511-522.

11. Boddy AV, Sludeden J, Griffin MJ, Garner C, Kendrick J, et al. (2007) Pharmacokinetic investigation of imatinib using accelerator mass spectrometry in patients with chronic myeloid leukemia. Clin Cancer Res 15: 4164-4169.

12. Arjomand A (2010) Accelerator mass spectrometry-enabled studies: Current status and future prospects. Bioanalysis 2: 519-541.

13. Bae SK, Shon JH (2011) Microdosing studies using accelerated mass spectrometry as exploratory investigational new drug trials. Arch Pharm Res 34: 1789-1798.

14. Faul MM, Slatter JG, Dean D, Smith K, Hesk D, et al. (2017) Industry practices for the synthesis of radioactive active pharmaceutical ingredient for use in human absorption, distribution, metabolism and excretion studies (A survey of current practices of $21 \mathrm{IQ}$ consortium member companies). 